\title{
Double-sided anchoring of a newly placed mid-gastric metal stent using novel dedicated over-the-scope clips to allow safe through-the-stent ERCP
}

The patient was an 85-year-old woman who had been diagnosed with advanced gastric cancer including diffuse peritoneal spread 3 months previously. She had recently been admitted after four cycles of palliative chemotherapy because of progressive signs of luminal occlusion, as well as jaundice. Laboratory assessment was significant for increased cholestasis parameters ( $\gamma$-glutamyltransferase $1084 \mathrm{U} / \mathrm{L}$, alkaline phosphatase $977 \mathrm{U} / \mathrm{L}$, bilirubin $0.6 \mathrm{mg} / \mathrm{dL}$ ) and minor systemic inflammation (C-reactive protein $3.4 \mathrm{mg} / \mathrm{dL}$ ). Therefore, antibiotic treatment was commenced for suspected cholangitis.

Standard upper gastrointestinal endoscopy confirmed a short, high grade malignant obstruction in the middle third of the stomach, while the distal antrum was found to be tumor-free after successful passage of a pediatric gastroscope ( Fig.1a). An uncovered $60 \times 20-\mathrm{mm}$ gastroduodenal self-expanding metal stent (SEMS; Taewoong Medical) was placed without difficulty, using a doublelumen gastroscope ( $\mathbf{F i g . 1} \mathbf{1}$ b). Two days later, after adequate spontaneous stent expansion, both the iso- and antiperistaltic stent ends were fixed by clips. To this end, we used a novel dedicated over-thescope (OTS) clip system (stentfix OTSC; Ovesco Endoscopy, Tübingen, Germany), which is an evolution of conventional OTS clip technology with indentations in the cap and brackets bowed to the outside to optimize engagement ( $\mathbf{F i g} \mathbf{1} \mathbf{1} \mathbf{c}, \mathbf{d}$ ). Following the switch to a therapeutic duodenoscope, careful advancement through the mid-gastric SEMS ( $\mathbf{F i g} \mathbf{2} \mathbf{a}$ ) proved easy. It was then possible, without further difficulty, to perform the endoscopic retrograde cholangiopancreatography (ERCP) procedure, including a freehand needle-knife precut ( $>$ Fig. $\mathbf{2}$ b) for difficult biliary access, and implantation of a biliary SEMS ( $>$ Fig. 2 c) for a short prepapillary high grade stricture ( $\vee$ Fig. 2 d; - Video 1).



$\checkmark$ Video 1 The video illustrates double anchoring of a mid-gastric self-expanding metal stent using stentfix OTSCs to allow through-the-stent endoscopic retrograde cholangiopancreatography.
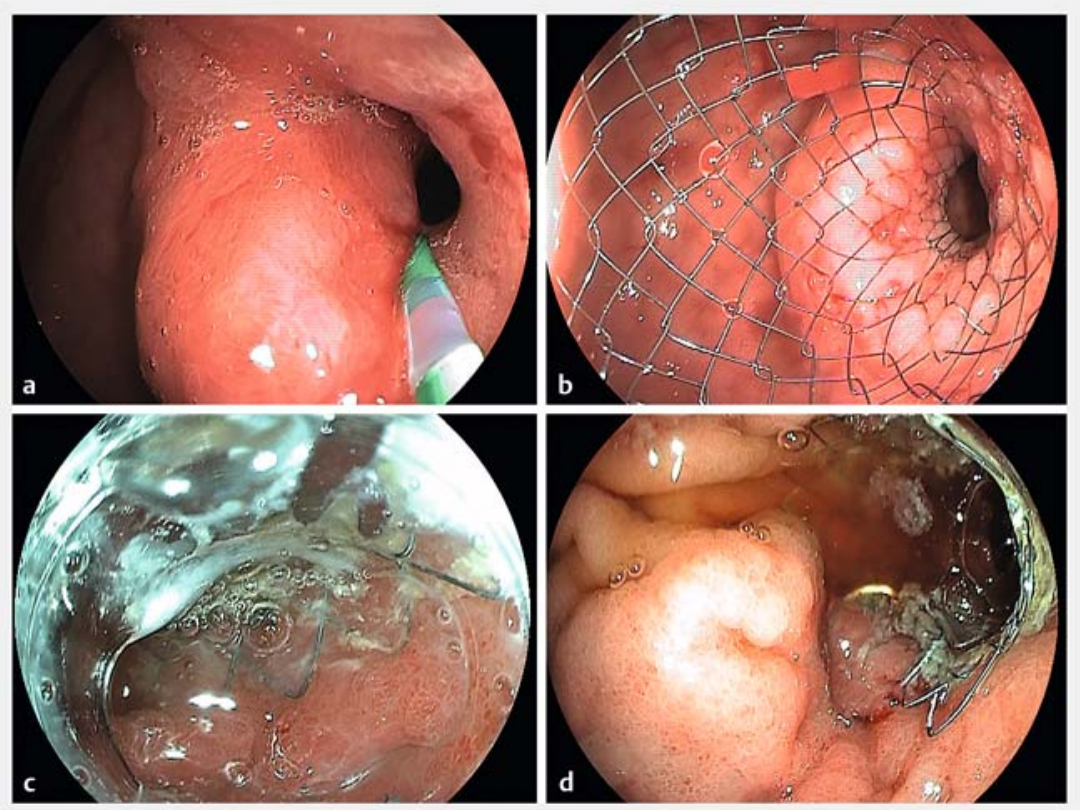

Fig. 1 Endoscopic views showing: a a short high grade stricture in the middle third of the stomach with a cannula for guidewire insertion; $\mathbf{b}$ a $60 \times 20$ - $\mathrm{mm}$ uncovered gastroduodenal self-expanding metal stent that has been inserted across the stricture; $c$ clip fixation of the oral end of the stent using a novel dedicated over-the-scope clip (stentfix OTSC) that has indentations in the application cap; $\mathbf{d}$ the final result with optimal and tight stent fixation (the differential bowing of the clip brackets compared with conventional over-the-scope clip technology is visible). 

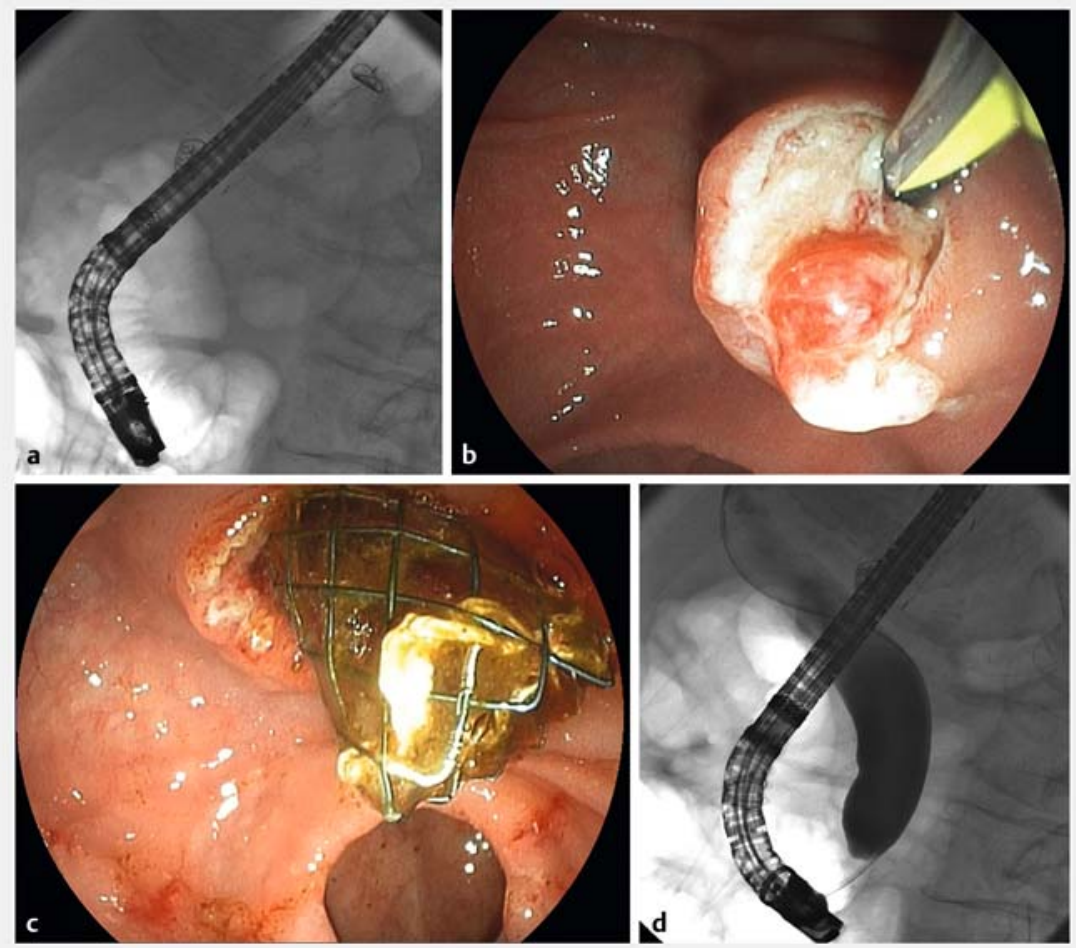

- Fig. 2 Views during endoscopic retrograde cholangiopancreatography (ERCP) showing: a uncomplicated duodenoscope advancement and short-axis en face positioning for throughthe-stent ERCP (note the fluoroscopic appearance of the stentfix OTSCs in situ; b successful freehand needle-knife precut access after failed guidewire cannulation; c, $\mathbf{d}$ implantation of a biliary self-expanding metal stent for a pre-papillary high grade stricture after maximumincision endoscopic papillotomy.

Combined biliary and gastroduodenal outlet obstruction typically arises in pancreatic cancer and is categorized by the Mutignani classification, which may guide clinical decision-making [1]. In contrast, the situation in this clinical report, with its combined mid-gastric and biliary obstruction, is quite uncommon, in addition to the pioneering novel concept of securing the stent for throughthe-stent ERCP by double-sided fixation [2]. As is illustrated herein, the innovative and recently marketed stentfix OTSC system enriches the endoscopist's toolbox in standard and special settings related to gastrointestinal stenting [3].

Endoscopy_UCTN_Code_TTT_1AO_2AF

Corresponding author

\section{Vincent Zimmer, MD}

Department of Medicine, Marienhausklinik

St. Josef Kohlhof, Klinikweg 1-5,

66539 Neunkirchen, Germany

Fax: +49-6821-3632624

vincent.zimmer@gmx.de

\section{References}

[1] Mutignani M, Tringali A, Shah SG et al. Combined endoscopic stent insertion in malignant biliary and duodenal obstruction. Endoscopy 2007; 39: 440-447

[2] Zimmer V. Gastrointestinal: Utilization of a novel dedicated stent fixation clip device ("stentfix OTSC") for an umbrella-type cardia stent. J Gastroenterol Hepatol 2020. doi:10.1111/jgh. 14993

[3] Perumpail RB. Gastrointestinal stents: Thinking outside the box. Techn Innov Gastrointest Endosc 2020. doi:10.1016/j. tige.2020.04.001

\section{Bibliography}

Endoscopy 2021; 53: E221-E222

DOI 10.1055/a-1244-9723

ISSN 0013-726X

published online 11.9.2020

(C) 2020. Thieme. All rights reserved.

Georg Thieme Verlag KG, Rüdigerstraße 14, 70469 Stuttgart, Germany

Competing interests

The authors declare that they have no conflict of interest.

The author

\section{Vincent Zimmer ${ }^{1,2}$}

1 Department of Medicine, Marienhausklinik St. Josef Kohlhof, Neunkirchen, Germany

2 Department of Medicine II, Saarland University Medical Center, Saarland University, Homburg, Germany

\section{ENDOSCOPY E-VIDEOS}

https://eref.thieme.de/e-videos

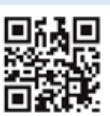

Endoscopy E-Videos is a free access online section, reporting on interesting cases and new techniques in gastroenterological endoscopy. All papers include a high quality video and all contributions are freely accessible online.

This section has its own submission website at

https://mc.manuscriptcentral.com/e-videos 